\title{
Understanding Religion As a Phenomenon in Workplace Sprituality: A Durkheimian Approach
}

\author{
Elif Baykal \\ İstanbul Medipol University
}

${ }^{1}$ Assoc. Prof., İstanbul Medipol University, Kavacık, Beykoz, Istanbul. E-mail: elif.baykal@medipol.edu.tr

Corresponding author:

Elif Baykal

E-mail:

elif.baykal@medipol.

edu.tr

eISSN: 2458-9675

Received: 10.03.2021

Revision: 19.05.2021

Accepted: 13.06.2021

(C)Copyright 2021

by Author(s)

\begin{abstract}
In this study, Durkheim's structural functionalism and his approach to religion and social solidarity will be used to gain an in-depth understanding of the workplace spirituality approach in management literature. In this context, workplace spirituality is defined as the inner lives of employees fueled by meaningful work that is realized in the context of a community. The concept of organizational spirituality, the ultimate aim of building strong connections within an individual's life and between his or her work colleagues, is defined by efforts to comply with specific beliefs and values in the workplace. In fact, it is more clearly understood as the strong relationships that employees will develop with each other, their jobs, and workplacep. As well as the views of famous structural-functionalist Durkheim on society and religion, the common approaches that can illuminate the possible impact of these views on workplace spirituality and spiritual leadership theories will be discussed in detail. Later, the position and function of religion in both Durkheimian and workplace spirituality approaches will be explained. Therefore, this study is important in giving a theoretical understanding of the importance of spiritual literature and its holistic viewpoint that overlaps with Durkheims views on religion.

Keywords:
\end{abstract}

Durkheim • Structural Functionalism • Workplace Spirituality • Spiritual Leadership

\section{İsyeri Ruhsallığında Bir Fenomen Olarak Dini Anlayabilmek: Durkheimcı Yaklaşım}

Öz

Bu çalışmada, Durkheim'ın yapısal işlevselciliği ve din ve sosyal dayanışmaya yaklaşımı, yönetim literatürüinde işyeri maneviyatı yaklaşımının derinlemesine anlaşılması için kullanılacaktır. Bu bağlamda işyeri maneviyatı, çalışanların anlamlı işlerle beslenen ve bir topluluk bağlamında gerçekleşen içsel yaşamları olarak tanımlanmaktadır. Örgütsel maneviyat kavramı, nihai amacı bireyin yaşamını, çalışma arkadaşlarını ve diğer insanlarla gelişim konusunda güçlii bir bağ kurmasını ve işyerinde inanç ve değerlerine uyma çabaları olarak tanımlanmaktadır. Çalışanların birbirleriyle, işleriyle ve işyerleriyle geliştirecekleri güçlï ilişkiler olarak açıklanabilir. Ünlui yapısal-işlevselci Durkheim'ın toplum ve din konusundaki görüsşleri tartışıldıktan sonra, bu görüşlerin işyeri maneviyatı ve manevi liderlik teorileri üzerindeki olası etkisini aydınlatabilecek ortak yaklaşımlar ayrıntılı olarak tartışılacaktır. Daha sonra hem Durkheimcı hem de işyeri maneviyat yaklaşımlarında dinin konumu ve işlevi açılklanacaktır. Bu nedenle, bu çalışma, manevi edebiyatın önemini ve Durkheim'ın din hakkındaki görüşleriyle örtiişen bütüincuil bakış açısını anlamak için teorik bir fikir vermesi açısından önemlidir.

Anahtar Kelimeler:

Durkheim •Yapısal İşlevselcilik •İşyeri Ruhsallığı • Spirituiel Liderlik 
In modern business life, individuals work in ambiguous, fragmented, and diversified 'workspaces' lacking spiritual fulfillment, often leaving employees to search for meaning in their lives and the work they do, and culminating in greater efforts to make sense of work and life (Narcikara, 2018, p.11). As Fry (2003) posits, rapid changes in today's modrn society triggered the transition from traditional, central, bureaucratic, and highly standardized, fear-oriented, and non-spiritual organizations to more humane, democratic, motivation-oriented, and flexible organizations (Fry, 2003). That is why, the classical management approach in traditional, bureaucratic, hierarchical, and central organizations cannot satisfy the differentiated needs of the employeep. Hence, an ethically based approach to management has gained importance and made people realize the importance of workplace spirituality. In fact, workplace spirituality literature has attracted attention to a rather neglected area: to the emotions and spirits at work (Mabey 2013). At this point, workplace spirituality and spiritual leadership, which are practically reflections of spirituality in the business environment, are seen as an important aids in solving problems in today's business life, and as a result, have attracted the attention of scientists and professionals (Kouzes and Posner, 2003; Fry, 2008; Chen \& Yang, 2012; Narcikara, 2017).

Individuals have both spiritual and material needs, and they come to work with these needp. Indeed, integrity of their inner realities and a sense of wholeness within their soul require satisfying both of these needs (Baykal \& Zehir, 2019, p. 124). With the help of workplace spirituality, as Chaskalson (2011) suggests, modern organizations embraced the view that we are not supposed to choose between economic prosperity and human well-being. Organizations can both make profit and satisfy their employees simultaneously. Therefore, spiritual leadership and workplace spirituality literature have come about as a reaction to declining, and some might argue, even a loss of values and ethical conduct in the workplace (Pio \& Tampi, 2018, p. 757).

Although in the workplace spirituality literature, it is stated that a holistic perspective is adopted for examining the effect of spirituality on individuals, the sociological aspect of spirituality on an organizational basis has not been adequately examined, and instead, a narrow approach limited with a management science perspective has been adopted. In this study, the effect of workplace spirituality on organizational members will be examined from a multidisciplinary perspective, taking Durkheim's holistic sociological perspective as a framework.

\section{Workplace Spirituality}

In human nature, there is a need for attachment. This need finally leads to the increase in the popularity of religious and spiritual teachings that attach people to their own selves and to their community. In this point, spirituality can be explained 
as the search for a vision involving service to other people, humility, care, altruism, transparency, and fairness that creates connectedness and inner peace. Spirituality is a universal force driving the need for self- transcendence and interconnectedness with all things in the universe and can be seen in groups and organizations (Kriger $\&$ Seng 2005). Thus, it should be accepted as a search for connectedness with the outer world and with the unifying source of one's life (Baykal, 2019, p. 50). It can be explained as a psychological pattern wherein a meaningful life, wholeness, and interconnectedness are melded in the same pot (Baykal \& Zehir, 2018, p. 124).

On the one hand, with an organization-level perspective, Ashmos and Duchon (2000) explain workplace spirituality as accepting the existence of an inner life that is nourished by meaningful work. It is the effort of pursuing an ideal of a higher purpose in organizational life (Cavanagh \& Hazen, 2008, p. 63). According to workplace theory, the more people have values congruent with their organization, the more they spend their effort to improve organization. That is why, nowadays, several companies give importance to using workplace spirituality in creating value congruence in organizations (Baykal, 2019a, p. 32). Reave (2005) claims that in those kinds of organizations wherein values that have long been considered as spiritual ideals, these values act as a positive influence on leadership succesp. Actually, workplace spirituality shows that in order to have an effective and successful organization, there is no need to give up spiritual values (Baykal, 2020, p. 81).

The concept of workplace spirituality can be considered as a second order concept that includes some important and widely accepted subdimensionp. For example, Tanwar \& Jain (2019) explained three main pillars that support spiritual workplace: self-work immersion, interconnectedness, and self-actualization. In this point self-work immersion is the engagement one experiences while working; interconnectedness is the situation wherein individuals enjoy being a member of the greater group, namely, their organization; and self actualization is being succesful at fulfilling one's potential. According to Pawar, the experiences of meaningful work and the sense of connectedness are two salient aspects of workplace spirituality (Pawar, 2016, p. 976). Similarly, Marques et al. (2005) explains that workplace spirituality should be accepted as "an experience of interconnectedness, felt by all people involved in the work process, triggered by the awareness that each member in the organziation is driven by an inner power that increases their sense of justice, humilty, and courage. In point of fact, although this unique concept includes many dimensions, the most widely accepted dimensions are, s: meaning at work, connectedness, and alignment with organizational values (Gupta et al., 2014), since it is the recognition that inner life nourishes and is nourished by meaningful work that takes place in the context of a social group (Ashmos and Duchon, 2000, p. 137). Decidedly all these categorizations refer to the creation of a community spirit at work that contributes to fairness, giving all stakeholders the right to participate in critical decisions (Baykal, 2019c, p. 48). 


\section{Spiritual Leadership}

Spiritual leadership refers to the process of motivating and influencing employees through a transcendent high level vision and an organizational culture that has its roots in altruistic love. Spiritual leadership emerges from an interaction of a leader's vision, deep caring for group members (altruistic love), and hope and faith (Sweeney \& Fry, 2012, p. 100). It is significant for the satisfaction of fundamental needs of both leaders and followerp. In the spiritual leadership approach it is believed that spiritual well-being is possible through a membership that encompasses a widely accepted organziational vision and perfect value congruence in all individual, group, and organization levelp. The ultimate benefit of embracing spiritual leadership is fostering greater well-being, commitment and productivity, social responsibility, and performance excellence (Fry and Nisiewicz 2013; Fry and Slocum 2008). The incorporation of positive organizational and personnel outcomes should be accepted as a holistic approach unique to spiritual leadership theory (Yang \& Fry, 2017, p. 308). In spiritual leadership theory, a simultaneous application of spiritual, ethical, and social values differentiates this leadership form from other positive leadership styles (Ali et al., 2020, p. 131), and the combination of spirituality with leadership and the workplace is considered as a solution for the ills of modern society (Samul, 2020, p. 1).

Fry (2003) posits that spiritual leadership is based on three important components enveloping vision, hope/faith, and altruism. In spiritual leadership, a leaders' system of beliefs about virtues and values influence their perceptions and judgments in moral and ethical issues (Sweeney and Fry, 2021, p. 90). According to Fry, this vision reflects an organization's purpose, its main reason for existence, and the formation of significant stakeholders (Fry 2003): It is the power of the leader in giving direction to the whole organization. Fry explains hope as the feeling felt by organizational members in attaining the above mentioned vision. Hope in spiritual leadership is not a mere anticipation or an unbacked faith in attaining goals but rather an intricately detailed road map, a shrewd strategic plan involving alternatives for reaching certain goals that are beneficial for the whole organization. Moreover, Fry (2003) explained altruistic love as a wholeness, harmony, and well-being built through care, concern, and appreciation for both one's own self and for others. In altruistic organizations, people take care of each other, embracing benevolent behavior for each other.

Calling is used to define the properties of a professional (Fry 2003) wherein employees embrace the organizational vision, love their work, and find their work meaningful and useful. Furthermore, by membership he refers to the situation whereby all organizational members appreciate each other with compassion and care, thus promoting the sense of belonging and connectedness. Through spiritual leadership, leaders create a vision wherein leaders and organizational members experience this sense of calling, and their lives gain purpose and meaning. Moreover, they establish 
an organizational culture encompassing altruistic love, belonging, and feelings of appreciation (Fry et al., 2016, p. 249).

Similarly, Fry (2003), thinks membership meets one of the most important needs of individuals, that is to say, to be understood and appreciated. He suggests that, with the help of membership, when individuals devote themselves to their group, their lives gain meaning by identification with a network. Owing to spiritual leadership in organizations, altruistic love mutually bonds the organization and individuals in a common vision. This feeling removes the fears related to anxiousness, egoism, envy, anger, and guilt. It is unconditionally given (Fry, 2003) and culminates in a sense of connectedness, resulting in greater awareness regarding being understood and appreciated (Narcikara \& Zehir, 2016, p. 31). The intrinsic motivation caused by spiritual leadership facilitates the integration of individuals and teams with the organization's goals and values. Hence, empowered teams emerge that can effectively deal with key strategic stakeholder issues (Fry et al., 2010, p. 292). Spiritual leadership also provides the basis for learning organization, innovativeness, and empowerment, all necessary characteristics for driving organizational excellence in processes and outputs (Fry et al., 2010, p. 290).

Related literature ensures a considerable number of empirical proofs about positive outcomes of spiritual leadership in organizationp. In the extant literature we can come across myriads of positive organizational contributions to this unique leadership style. Studies show that spiritual leadership is effective in employee performance (Baykal and Zehir, 2018; Supriyanto et al., 2020). Additionally, there are multiple studies on the effects of spiritual leadership on job satisfaction (Yusof, 2011), on organizational performance (Fry et al., 2017; Salehzadeh et al. 2015; Narcikara, 2017), employee empowerment (Chegini and Nezhas, 2011), organizational commitment (Tsui et al., 2019), pro-environmental behavior (Afsar, Badir and Kiabi, 2016), job satisfaction (Supriyanto et al., 2016), lower levels of organizational silence (Abbas and Shyaa, 2019), and team productivity and life satisfaction (Jeon et al., 2013).

\section{Structural Functualism and Durkheim}

Structural functionalism is a theory in sociology and applied to organizations, claiming that the structures embraced by organizations are often functional and tend to make organizations more effective. Functionalism, used in this context, is the intent by individuals, especially by managers, to make their organization attain higher performance (Donaldson, 2008, p. 306). According to structural functionalism societies, groups and all kinds of social organizations are constituted of systemp. Durkheim, one of the most prominent advocates of structural-functionalism, is important for his systematic formulation of a functionalist approach in sociology (Coser and Rosenberg, 1969, p. 610). 
Structural functionalists' approach, regarding the organization, overlaps with many assumptions of general systems theory. According to Bowler (1981), one of the researchers who adopted the system approach, each system has a limit on what the system covers or excludes. The universe contains processes that unite and separate itself, and these processes continue their lives until another set of processes destroys them. Similarly, Durkheim suggests that a society maintains its life with the help of some social phenomenon, such as religion, making it different from other entitiep. Similarly, another system theorist, Churchman (1971), suggests that there should be a regulator and decision maker in the system in order to run it without problemp. When we turn our lens to Durkheim, he also suggests that there should be some widely accepted rules and regulations in the society to create a holistic mechanism capable of maintaining smooth and communal rituals, customs, and religion to perform this task. A more noteworthy overlap between system theory and Durkheim's views come from Bertalanffy, even supporting the holistic mindset of workplace spirituality and spiritual leadership. In Bertalanffy's (1955) approach, search for meaning and integrity are two prevelant properties of systems (as it is assumed in holistic suggestions of spirituality literature and importance) given to meaningful work (Fairholm, 1998; Fry, 2003; Reave, 2005) for attaining a healthy and high performance organization.

In Durkheims's approach, collective beliefs are important in the path through which society becomes aware of itself, since they contribute to the expression of the homogeneous physical movements constituting the ritual, as opposed to the other way around (Bellah, 2005, p. 184). According to Durkheim, the stimulating action of society is not experienced merely in exceptional situationp. Actually, an individual is in moral harmony with others in the society, gaining confidence, courage, and boldness in action, like the believer who believes the eyes of his god are on him (Durkheim, 1995, p. 213). This perspective regarding society perfectly matches with the workplace spirituality literature's approach (Mitroff \& Denton, 1999). Giacalone \& Jurkiewicz, 2003) claimed that society is an organic entity nourished with altruism and care, making membership in the group appealing for individuals. Similarly, in the Durkheimian perspective, the culture of the society is not only an instrument triggering action but also a source of motivation working through emotions and collective action (Simith \& Alexander, 2005, p. 15). Durkheim further suggests that ritual is a powerful tool used by religion in affecting people, and it both makes them feel and be stronger (Olaveson, 2001, p. 91).

\section{Durkheim and Religion}

Durkheim considers religion and a common morality as essential to and pervasive in modern societiep. Religion and shared morality in society are accepted as sacred in Durkheim's mindset. By spirituality, Durkheim understands religion to be a 
significant matter related to meaning and morality in modern societies (Tole, 1993, p. 1). Durkheimian sociology emphasizes the importance of the collective nature of the system of values and ideals which give meaning to individual livep. In his societal approach, objects, rituals, and events can be accepted as some of the possible concretizations of ideals whereby society regulates itself (Tole, 1993, p. 11).

Durkheim's approach is significant in making it clear that religion, or in our context spirituality, is not something divine, rather it is a product of society. Durkheim also identified important points regarding religion and its effects within a society, considering religion as the source of solidarity and identification for the members within a society, Durkheim claims that religion provides meaning for life, reinforcing the collectively held morals and social norms within a society. Rather than accepting religion as a mere fantasy, Durkheim thinks it is a critical component of the social system. As in the case with most religions, the individual in a society fears its authority, but also knows he will literally cease to exist as an individual without it (Durkheim, 1953, p. 73), thereby religion culminates in social control, alignment, and purpose. In fact, it provides a means of communication and creates social normp. However, as in the case with the more secular version of workplace spirituality (Fry, 2003; Narcikara, 2017), religion or spirituality is not necessarily something divine, rather it is something socially constructed. Durkheim posited that religion has the power to unite its adherents into a "single moral community (Stark et al. 1983, p. 121). Similarly, being inspired by Durkheim, Talcott Parsons (1979) also claims that religion serves the purpose of integrating the social norms and provides non-negotiable grounds for the ethics and rules that have their roots in religion. As opposed to criticisms directed toward Durkheim, he does not think that science refuses to grant to religion its right to exist, rather it refuses the right of religion to dogmatize (Durkheim,1973, p. 205).

To Durkheim, religion comes about and is legitimized through "collective effervescence." Collective effervescence explains the moments in social life in which members of a society come together with the aim of performing a religious ritual. Religious rituals are the mechanism through which the society or the group worships and reaffirms its solidarity (Durkheim, 1915).

At some point, Durkheim deified society. In fact, he believes that he killed two birds with one stone. From his point of view, deification of society is disguised as socialization of God. Durkheim claims that through the entire history "God" acts as a fanciful representation of the will of society (Bauman, 2005, p. 370). He claims that in the future, religions will no longer be able to affect the consciences of individuals deeply (Durkheim, 1951, p. 375), but at the same time he does not claim that religion will be replaced by science and actually believed in the eternity of religion since 
he claimed that serves as the primary foundation of social solidarity (Gofman, 2019 , p. 29). Indeed, most of the enlightened sociologists consider modernity as a clue for the point at which religion's effect on institutional and cultural life ends, and furthermore, as a signal to the end of the sociocultural order of the premodern society. But, Durkheim's approach embraces a deep appreciation of the performance of religion in social life, specifically in the point that it generates institutionally differentiated and culturally pluralistic societies (Tole, 1993, p. 2). Actually, for Durkheim, modernization does not encompass the dissolution of religion. Indeed, Durkheim never suspected religion's effect as a fundamental and enduring feature of society (Tole, 1993, p. 2).

Furthermore, Durkheim accepted totemism as an integral part of his work since he was convinced that religions are built and remade (Shilling, 2005, p. 213). As to Durkheim, totemism is a kind of ritual religious practice that encompasses the symbolic equation of a comunity with an object, animal, plant, or symbol. He suggests that the totem is the symbol of both the god and society," a kind of idealization of the group or community and an effervescent symbol through which society is expressed (Shilling, 2005, p. 214). The symbolic order can increase a member'sdignity, allowing them to benefit from the advantages of a common life and increasing the importance of connectedness within the group.

In Durkheim's approach, the ideal society is not something outside the real society; it is not composed of merely the mass of members composing it but rather encompasses the ground that they occupy, the tools they use, the attitudes and the religious beliefs they embrace (Durkheim; 1964, p. 422) Actually, society is not an external, objective reality designating behavioral standards but is effective on individual consciousnesses, hence operating as an internal behavioral regulator (Tole, 1993, p. 5).

\section{Durkheim's Structural Functualism and Fry's Spiritual Leadership Theory}

The functionalist tradition is significant in the point that it assumes that social systems meet certain requirements and suggests that there are functional imperatives that should be met for the survival of a group (Chilcott, 1998, p. 103). Actually, Durkheim claims that a functionalist should be conceived as the one that views society as a system: that is to say, a whole composed of interrelated parts, assumes the existence of a tendency toward systemic equilibrium, and thinks about the possibility of social order (Pope, 1975, p. 361). In that point, Durkheim's structural functionalism coincides with Fry's spiritual leadership theory in the point that both of them view the social group as a system, composed of interrelated and interdependent partp. In Durkheim's approach, wholes should be conceived as systems of forces limiting and nourishing each other and creating an equilibrium" (1961a, p. 233). Similarly, Fry (2003) tried to create a holistic picture of organization wherein both the leader and 
followers supports, nourishes, and when necessary, limits each other, thus creating an equilibrium wherein everyone is in a win-win position.

Durkheim considered integration, cohesion, and solidarity as regulatory mechanisms for controlling the society (Pope, 1975, p. 363); whereas, for Fry (2003, 2005), it is the leader who acts as the main regulating force but the tools that are used by this leader are quite similar: They both give importance to being connected to a society and view a sublime society as the main regulator in social relationships. According to Durkheim (1974, p. 212), law and morality ensure the equilibrium of society by providing the necessary means to adapt to new conditions. As in the case with the role of spirituality in workplace spirituality and spiritual leadership theories, in Durkheim's approach, it is posited that religion also has a social role, enabling individuals to overcome several problems and paradoxes that are apparent both in the secularization theories and in the theories that focus on rational choice and religious economy. However, according to Durkheim, secularization made the mistake of taking a linear and causal approach to studying the relationship between modernization and religion. Even though secularism restored the autonomy of religious institutions, they were unsuccesful in grasping the main operating principles of religions (Pace, 2017, p. 350) and could not get use of it.

As in the case with the workplace spirituality approach (Marques, 2008), in Durkheim's approach, the central concern is collective well-being (Gorski, 2017, p. 81). As the proponents of workplace spirituality (Giacalone \& Jurkiewicz, 2003; Milliman, Czaplewski \& Ferguson, 2003), Durkheim also rejects the life of mere pleasure and suggests that genuine happiness comes as a result of collective well being created by the regulation and reordering of our initial nature and of our inner life (Gorski, 2017, p.82). In Durkheim's approach, the most important component of character is the capacity to restrain one's own self and reins in passions and desirep. But, according to Durkheim, this reigning inshould be melded with an instinct for social good (Gorski, 2017, p. 83). In spiritual leadership theory and in workplace spirituality theory, the concepts of altruism, membership, and interconnectedness within the group emphasizes the same assumption, that is to say, the importance of common good, the benefits of being connected to the group and putting the good of the group above individuals.

\section{Connectedness in Spirituality Literature and Durkheim's Social Solidarity}

As Pfeffer (2003) suggests, individuals are inclined to value their affiliations, enjoy being connected and part of a larger community where they can have relationships with other members of their society or group. Workplace spirituality involves values leading to a sense of transcendence and interconnectedness resulting from the fulfillment of work. Actually, an integrated inner life and wholeness of soul, body, and mind are 
possible through workplace spirituality. Indeed, spiritual leadership provides the climate for individuals to live their inner life and meet their spiritual needs at work (Narcikara \& Zehir, 2016, p. 30). People working in these kinds of organizations wherein workplace spirituality is embraced as a corporate philosophy feel that they are an organic part of a whole in which they can live their true selves authenticly, without fear of being condemned, limited, oppressed, and manipulated by corporate values.

For Durkheim, the collective effervescence, the effective experience engendered amidst rituals, is an important means for reaching the origin of the sacred. With an overall functionalist approach, Durkheim sees rituals as a tool for maintening group cohesiveness and communal identity (Heinämäki, 2009, p. 68). As Durkheim himself underlines, repeated performance of rituals prevents the beliefs from fading away in time (Jones, 2005, p. 117), and is- the main reason as to why social groups prefer to embrace some special rituals for themselves in order to nourish the interconnectedness of their members.

Durkheim explains social solidarity involves shared commitment to social practices that is possible through law and custom or group norms (Adair, 2008, p. 106). Durkheim also posited that the laws and regulations in themselves are also manifestations of the evolution of social solidarity and moral sentiments (Johnsan et al., 2019, p. 649). Actually, a good society is one that has neither too much integration and regulation nor too little, with the actual mean can be understood only in relation to a given society (Gorski, 2017, p. 82). For both workplace spirituality scholars (Aschon \& Duchon, 2005; Fry \& Slocum, 2008) and for structural functionalist Durkheim $(1915,1974,1995)$, a coherant and satisfying social group is possible through spirituality. In both approaches spirituality is a means to reach harmony. In fact, neither of these approachs exalt spirituality for the sake of divine ends.

Durkheim suggests that anomie is unnatural and transient. Hence, an organic solidarity will inevitably develop that will support the interdependencies in a society or group with complex division of labour (Johnsan et al., 2019, p. 650). In that point, when we turn our lens to workplace spirituality, we notice the same approach in handling interdependenciep. Workplace spirituality also suggests that when people have high levels of inerconnectedness within their social group, namely within their organization, they experience greater well being and a sense of meaning at work.

According to Durkheim, solidarity and regulations in society are two important features of morality. In his approach it can not be separated from social solidarity, and in fact, sometimes coincides with it. The level of morality in the group, at the same time, shows differences according to the level of solidarity. Because, if social life starts to vanish, moral life also starts to vanish, having no object to cling to (Durkheim, 1997, p. 331). In spiritual leadership literature, Fry (2003) also suggests that altruism among the Organizational members nourishes an ethical business 
environment that has its roots in morality, care, and love for collegues, and satisfying leader-member relationships.

\section{Discussion}

In this study, understanding the perspectives of spirituality literature and Durkheim's structural functionalist approach was the purpose, particularly in regards to Durkheim's understanding about society and the function of the sacred in the society. Furthermore, this study revealed that there are important overlapping points in their understanding about the function of spirituality and society. First of all, both approach a holistic perspectives in the effects of spiritual values within individuals' lives. They both perceive religion and spirituality as a natural cement creating a kind of coherence in both individual and social levels (Dinçer, Baykal \& Yüksel, 2020). As we have elaborated before, Durkheim thinks social solidarity is a natural consequence of an advanced division, that is to say society. He suggests that society is an important tool in creating connectedness and coherence among individuals, as it is suggested in spirituality literature.

In Durkheim's approach, the ideal society is not something outside the real society and is not composed of merely the mass of members composing it, but in contrast, it encompasses the ground which they occupy, the tools they use, and the attitudes and religious beliefs they embrace (Durkheim, 1964, p. 422). Actually, society is not an external, objective reality designating behavioral standards but is effective on individual consciousnesses, hence operating as an internal behavioral regulator (Tole, 1993, p. 5). Similarly, spirituality can act as an intrinsic motivator and internal control mechanism, aligning individuals' behaviours and attitudes with their values and convictionp. Religion or other similar spiritual values are considered as a glue, linking individuals to each other and aligning individual realities with those of their groupp. As it is assumed in workplace spirituality literature, Durkheim also assumes that there are two primary anthropological needs of mankind: the first is social or group belonging and the second is value regulation (Gofman, 2019, p. 29): society has the potential to meet both of these needp. Moreover, in Durkheim's philosphy, as in the case in the workplace spirituality approach, this value regulation is possible through spiritual mechanisms, that is to say, religion can act as a tool for creating solidarity and for regulating the society.

\section{Conclusion}

Even though Durkheim has written on quite a considerable number of subjects, he is usually identified with the functionalist model of social analysis, since he has given great importance to religion in his work throughout his career (Olaveson, 2001, p. 91). According to Durkheim, religion has the primary role of assuring the equilibrium of 
society and adapting it to external conditions (Olaveson, 2001, p. 91). For Durkheim, in the evolution of religion, the sacred has become more and more transcendent and universalistic (Tole, 1993, p. 18), thus overlapping with what is understood as spirituality in the extended literature (Tacey, 2004). Religion is something above human, something powerful and effective, thereby creating a higher level goal and meaning in life. In fact, in spiritual literature, religion is also considered as a social tool, rather than being respected as an ethereal purpose. To sum up, religion is on stage with a worldly function. Supporting our analysis related to his approach, Durkheim insists that contrary to pure positivist mindset, religion should no longer be understood as an inexplicable hallucination of some sort. Since it has gained a foothold in reality," he posits that religious forces are real," even though science denies the effect of religion in principle. From both perspectives, it can be concluded that when people have the opportunity to live their own spirituality in their social environment, this strengthens their loyalty within the society they are in, ensures the social order, and ensures the efficient functioning of social systems as a social regulator. So, with the perspectives of both approaches, religion should be viewed as a social tool creating a holistic reality rather than a heavenly conviction that is merely about the afterlife.

\section{References}

Abbas, A. A., \& Shyaa, H. H. (2019). The Role of the Spiritual Leadership in Increasing the Perceived Organizational Support and its Reflection on Decreasing the Organizational Silence by Computer Sciencep. TEST Engineering \& Management, 81, 3687-3714.

Adair, S. (2008). Status and solidarity: A reformulation of early Durkheimian theory. Sociological Enquiry. 78(1), 97-120.

Afsar, B., Badir, Y., \& Kiani, U. P. (2016). Linking spiritual leadership and employee proenvironmental behavior, The influence of workplace spirituality, intrinsic motivation, and environmental passion. Journal of Environmental Psychology, 45, 79-88.

Ali, M., Aziz, P., Pham, T. N., Babalola, M. T., \& Usman, M. (2020). A positive human health perspective on how spiritual leadership weaves its influence on employee safety performance, $p$. The role of harmonious safety passion. Safety science, 131, 104923.

Ashmos, D.P., \& Duchon, D. (2000) Spirituality at Work, p. A conceptualization and measure. Journal of Management Inquiry, 9 (2), 134-145.

Bauman, Z. (2005). Durkheim's society revisited. The Cambridge Companion to Durkheim, 360-382.

Baykal, E. (2019a). Person Organization Fit, p. Spiritual Way To Boost Performance. Asya Studies, 3(9), 31-43.

Baykal, E. (2019b). Participation Banks, p. A Suitable Environment For Workplace Spirituality. Mevzu-Sosyal Bilimler Dergisi, (2), 43-63.

Baykal, E. (2019c). Spiritual Leadership in Collectivist Cultures: Turkey Example. In Science and Spirituality for a Sustainable World: Emerging Research and Opportunities (pp. 44-69). IGI Global.

Baykal, E. (2020). Mindfulness and Mindful Coaching. In Handbook of Research on Positive Organizational Behavior for Improved Workplace Performance (pp. 72-85). IGI Global. 
Baykal, E., \& Zehir, C. (2018). Mediating effect of psychological capital on the relationship between spiritual leadership and performance. Ekonomika a management,11(3), 124-140.

Bellah, R. N. (2005). Durkheim and ritual. The Cambridge Companion to Durkheim, 183-210.

Bowler, T. D. (1981). General systems thinking, p. Its scope and applicability (Vol. 4). North Holland.

Chen, C. Y., \& Yang, C. F. (2012). The impact of spiritual leadership on organizational citizenship behavior, p. A multi-sample analysip. Journal of business ethics, 105(1), 107-114.

Chilcott, J. H. (1998). Structural functionalism as a heuristic device. Anthropology \& education quarterly, 29(1), 103-111.

Churchman, C. W. (1971). The design of inquiring systems basic concepts of systems and organization.

Dinçer, H., Baykal, E., \& Yüksel, P. (2020). Analysis of spiritual leadership and ethical climate for banking industry using an integrated IT2 fuzzy decision-making model. Journal of Intelligent \& Fuzzy Systems, (Preprint), 1-13.

Donaldson, L. (2008). Ethics problems and problems with ethics, p. Toward a pro-management theory. Journal of Business Ethics, 78(3), 299-311.

Durkheim, E. (1915). The elementary forms of the religious life, tranp. Joseph Ward Swain (New York, 1915). See also Edward Shils, Center and Periphery, p. Essays in Macrosociology (Chicago, 1975).

Durkheim, E. (1953). Value judgments and judgments of reality. Sociology and philosophy, 80-97.

Durkheim, E. (1974). Individual and collective representationp. Sociology and philosophy, 1-34.

Durkheim, E. (1997). The division of labor in society (W. D. Halls, Tranp.). New York, p. The Free Presp.

Durkheim, E., Herkommer, P., Herkommer, H., Dörner, K., \& König, R. (1973). Der selbstmord. Neuwied, p. Luchterhand.

Durkheim, E. (1965). The elementary forms of religious life. London, Tavistock Publications.

Fairholm, G. W. (1998). Leadership as an exercise in virtual reality. Leadership \& Organization Development Journal.

Fry, L. W. (2003). Toward a theory of spiritual leadership. The leadership quarterly, 14(6), 693-727.

Fry, L. W., Latham, J. R., Clinebell, P. K., \& Krahnke, K. (2017). Spiritual leadership as a model for performance excellence, p. a study of Baldrige award recipientp. Journal of Management, Spirituality \& Religion, 14(1), 22-47.

Fry, L.W., \& Slocum, J. (2008). Maximizing the triple bottom line through a strategic scorecard business model of spiritual leadership. Organizational Dynamics, 31 (1), 86-96. Garg, N., Punia, B. K., \& Jain, A. (2019). Workplace spirituality and job satisfaction, p. exploring mediating effect of organization citizenship behaviour. Vision, 23(3), 287-296.

Fry, L. W., Matherly, L. L., \& Ouimet, J. R. (2010). The spiritual leadership balanced scorecard business model, p. The case of the Cordon Bleu-Tomasso Corporation. Journal of Management, Spirituality and Religion, 7(4), 283-314.

Giacalone, R. A., \& Jurkiewicz, C. L. (Edp.). (2003). Handbook of workplace spirituality and organizational performance. Me Sharpe.Giacalone, R. A., \& Jurkiewicz, C. L. (Edp.). (2003). Handbook of workplace spirituality and organizational performance. Me Sharpe.

Gofman, A. (2019). Tradition, Morality and Solidarity in Durkheim's Theory. Sosyoloji Dergisi/ Journal of Sociology, 39(1), 25-39. 
Gorski, P. P. (2017). Recovered goods, p. Durkheimian sociology as virtue ethicp. In Varieties of Virtue Ethics (pp. 181-198). Palgrave Macmillan.

Gupta, M.; Kumar, V.; \& Singh, M. (2014). Creating satisfied employees through workplace spirituality, p. A study of the private insurance sector in Punjab (India). Journal of Business Ethics, 122 (1), 79-88.

Haldorai, K., Kim, W. G., Chang, H. P. and Li, J. J. (2019). Workplace spirituality as a mediator between ethical climate and workplace deviant behavior. International Journal of Hospitality Management, 102372.

Heinämäki, E. (2009). Politics of the Sacred, p. Eliade, Bataille and the fascination of fascism. Distinktion, p. Scandinavian Journal of Social Theory, 10(2), 59-80.

Jeon, K. P., Passmore, D. L., Lee, C., \& Hunsaker, W. (2013). Spiritual leadership, p. A validation study in a Korean context. Journal of Management, Spirituality \& Religion, 10(4), 342-357.

Johnson, P., Brookes, M., Wood, G., \& Brewster, C. (2017). Legal origin and social solidarity, p. the continued relevance of Durkheim to comparative institutional analysip. Sociology, 51(3), 646-665.

Jones, R. A. (2003). Emile Durkheim. The Blackwell companion to major classical social theorists, 193.

Kriger, M., \& Seng, Y. (2005). Leadership with inner meaning, p. A contingency theory of leadership based on the worldviews of five religionp. The leadership quarterly, 16(5), 771-806.

Kouzes, J. M., \& Posner, B. Z. (2003). The leadership practices inventory (LPI), in Participant's workbook (Vol. 47). John Wiley \& Sonp.

Mabey, C. (2013). Leadership development in organizations, p. Multiple discourses and diverse practice. International Journal of Management Reviews, 15(4), 359-380.

Marques, J. (2008). Spirituality at work: Internal growth with potential external challenges. The Journal for Quality and Participation, 31(3), 24.

Marques, J., Dhimand, P., \& King, R. (2005). Spirituality in the workplace, p. developing an integral model and a comprehensive definition. The journal of American academy of business, 7(1), 81-92.

Milliman, J., Czaplewski, A. J., \& Ferguson, J. (2003). Workplace spirituality and employee work attitudes, p. An exploratory empirical assessment. Journal of organizational change management, 16(4), 426-447.

Mitroff, I. I., \& Denton, E. A. (1999). A study of spirituality in the workplace. Sloan management review, 40(4), 83-84.

Narcıkara, E. (2017). Spiritüel liderlik davranışının algılanan performans üzerine etkisi. Yayınlanmış Doktora Tezi, Yıldız Teknik Üniversitesi, İstanbul.

Narcıkara, E. B. (2018). Spiritüelite (Ruhsallık) ve iş ortamında anlam arayışı. Alanya Akademik Bakış Dergisi, 2(1), 11.

Narcıkara, E. B., \& Zehir, C. (2016). Effect of Organizational Support in the Relationship between Spiritual Leadership and Performance., International Journal of Humanities and Social Science, 6(12), 29-42.

Olaveson, T. (2001). Collective effervescence and communitas, p. Processual models of ritual and society in Emile Durkheim and Victor Turner. Dialectical Anthropology, 26(2), 89-124.

Pace, E. (2017). Systems theory and religion. Civitas-Revista de Ciências Sociais, 17(2), 345-359.

Parsons, Talcott. Social system. New York, Routledge, 1979. 
Pawar, B.P. (2016), «Workplace spirituality and employee well-being, p. an empirical examination”, Employee Relations, Vol. 38 No. 6, pp. 975-994. https, p. //doi.org/10.1108/ER11-2015-0215

Pfeffer, J. (2003). Business and the spirit. In R. A. Giacalone \& C. L. Jurkiewicz (Edp.), Handbook of workplace spirituality and organizational performance (pp. 29-45). New York, p. M. E. Sharp.

Pio, R. J., \& Tampi, J. R. E. (2018). The influence of spiritual leadership on quality of work life, job satisfaction and organizational citizenship behavior. International Journal of Law and Management. 60(2), 757-767.

Reave, L. (2005). Spiritual values and practices related to leadership effectivenesp. The leadership quarterly, 16(5), 655-687.

Salehzadeh, R., Pool, J. K., Lashaki, J. K., Dolati, H., \& Jamkhaneh, H. B. (2015). Studying the effect of spiritual leadership on organizational Performance: An empirical study in hotel industry. International Journal of Culture, Tourism and Hospitality Research, 9(3), 346-359.

Smith, P., \& Alexander, J. C. (2005). Introduction, p. the new Durkheim. The Cambridge Companion to Durkheim, 1-37.

Stark, R., Doyle, D. P., \& Rushing, J. L. (1983). Beyond Durkheim, p. religion and suicide. Journal for the Scientific Study of Religion, 120-131.

Supriyanto, A., Ekowati, V., \& Maghfuroh, U. (2020). Do organizational citizenship behavior and work satisfaction mediate the relationship between spiritual leadership and employee performance? Management Science Letters, 10(5), 1107-1114.

Sweeney, P. J., \& Fry, L. W. (2012). Character development through spiritual leadership. Consulting Psychology Journal, p. Practice and Research, 64(2), 89.

Tacey, D. J. (2004). The spirituality revolution, $p$. The emergence of contemporary spirituality. Psychology Press.

Tole, L. A. (1993). Durkheim on religion and moral community in modernity. Sociological inquiry, 63(1), 1-29.

Tsui, K. T., Lee, J. C. K., Zhang, Z., \& Wong, P. H. (2019). The Relationship Between Teachers' Perceived Spiritual Leadership and Organizational Commitment, A Multilevel Analysis in The Hong Kong Context. Asian Journal of Social Sciences \& Humanities, 8(3), 55-72.

Usman, A., \& Danish, R. Q. (2010). Spiritual consciousness in banking managers and its impact on job satisfaction. International Business Research, 3(2), 65.

Yang, M., \& Fry, L. W. (2018). The role of spiritual leadership in reducing healthcare worker burnout. Journal of Management, Spirituality \& Religion, 15(4), 305-324.

Yusof, J. M. (2011). Spiritual leadership and job satisfaction, p. A proposed conceptual framework. Information Management and Business Review, 2(6), 239-245. 
